International Harvester, the U.S. South, and the Makings of International Development in the Early $20^{\text {th }}$ Century

"For the liberal foreign policy establishment of these decades, internationalism was the fruition of American nationalism, a global manifest destiny underpinned by growing economic dominance.” N. Smith, American Empire, p. 455.

"Although there are occasions when a revolutionary movement or visionary announces a grand plan for the total transformation of society ... more often programs of intervention are pulled together from an existing repertoire, a matter of habit, accretion, and bricolage." T. Li, The Will to Improve, p. 6

In 1913, International Harvester (IH), one of the United States' largest international corporations, published a booklet comprised of photographs of farmers using IH equipment in different parts of the world called 100 Harvest Scenes Around the World. It was produced by what the corporation called its 'service bureau,' a division of the advertising department dedicated to, in the company's words, "broader service to humanity" (Cooley, 1922, p. 7). That service is evident on each page, as the company provided geography lessons to its readership (these booklets were given out at minimal cost to customers) via photographic images of the various ways that harvesting was conducted in the United States, Canada, Europe, Asia and Africa. All of the images were of the same size and were framed with identical decorative borders, aesthetically uniting the different regions of the world into a whole and at a cursory glance suggesting parity among nations (see fig. 1). Yet closer examination reveals otherwise. Most of the images of countries in Africa and Asia for example depict farmers using nonmechanized farming implements, what IH would have considered "primitive" tools, while farmers in the United States, Canada and much of Europe are for the most part shown using the latest IH models of harvesters and reapers. This spatial division of the world into what were 
considered modern and primitive was transposed into a temporal one. The booklet opens with a brief overview of the history of farming technologies that is illustrated with a contemporary photograph of an Egyptian farmer using an oxen-pulled plow (see fig 2). The caption of the image-- "Plowing in Ancient Days - Egypt" - suggests that Egypt is meant to represent Europe's past, a fairly common trope of late Victorian American and European society.

Taken together, then, this group of 100 images of farmers in different regions of the world, some "modern" in their use of mechanized farming technology, some considered less so, and some used to represent a past time, suggests that IH was a participant in what scholars have argued was a dominant mode of geoeconomic imaginings in the early $20^{\text {th }}$ century (Cowen $\&$ Smith, 2009; Domosh, 2013; Massey, 2005; McClintock, 2013; Sparke, 1998, 2007). This vision characterized the world view of many US economic elites, who believed that every nation and all peoples could be made "modern" through the purchase of American commodities; all potentially equal through commercial development (Domosh, 2006). ${ }^{1}$ This form of flexible racism represents a shift in the US from a fixed, biological understanding of race, to a more flexible, sociological or economic understanding of race (Schulten, 2001). In their brief introduction to the section on Asia, the IH authors put this notion into words: "Modern methods and machines have not yet been introduced to any measureable extent, and as soon as they are, India will become a considerable factor in commerce. It may be interesting to note in passing that the first blast furnace in India has just begun operations, and steel rails are now being introduced ... Asia will inevitably become a large market for American and European manufactures"(International Harvester Corporation, 1913). Mechanization, in other words, is in

\footnotetext{
${ }^{1}$ This imagined view of what constitutes modernity - the purchase of American-made, mechanized, commodities assumes that those purchases will remake people into modern, disciplined subjects. Used as forms of advertisements, the visual and verbal conflation of modern commodities with "modern" peoples was meant to suggest this transformation. See (Burke, 1996; Laird, 1998; Lears, 1994).
} 
the process of transforming India into a modern nation just as it had transformed the United States, and American products are both signs of that transformation and the results of it.

This notion of flexible racism - of "difference" being transformed through the power of commodities - also seemed to characterize IH's perspectives on some of its domestic customers. Although the American South is given very short shrift in this pamphlet, in other ways, this American region figured prominently in the company's "service" activities. For example, figure 3 is part of a large set of photographs taken by employees of the company on their travels through the American South as part of their agricultural extension work. This particular image, taken in Enon, Alabama in February of 1915, could be read as depicting a scene even more "primitive" than the one of Egypt; suggesting as it does that women and children are working in the fields using a labor-intensive, ox-driven walking plow. Alabama is being presented, in other words, as if it was a primitive and undeveloped region of the world. The original caption for the photo makes the point clear: "This picture was not taken in Egypt not India nor Africa but in Alabama near Enon and shows the primitive methods still in use among the miserably poor colored people of the south." The domestic, or at least a part of it, is being imagined through the lens of the international. International Harvester, one of the largest international corporations in the United States (Carstensen, 1984; Domosh, 2006; Rosenberg, 2011), was seemingly engaged in producing and reproducing a set of complex geography lessons about the power of technology to transform the "primitive" into the "modern" in the "undeveloped" regions of Egypt and Alabama. On the eve of America's ascendency as a global economic power, IH and other major American corporations were envisioning the international as an extension of the national (and certainly not as its opposite (see Anderson, 2002; Malkki, 1994)) and were beginning to develop practices of intervention (this, of course, in addition to their comprehensive national and 
international sales practices) within the frame of the nation that would serve as a practicing ground for their later overseas interventions.

As Neil Smith has argued, this "global manifest destiny" - the notion that the economic expansion of American corporations would continue unabated beyond U.S. borders - was at the center of the liberal internationalism espoused by Woodrow Wilson and fellow foreign policy advisors (Smith, 2003). It was a notion, according to Smith, that characterized the first pivotal moment in the making of an American empire in the $20^{\text {th }}$ century; a vision that saw foreign economic expansion as the "fruition" of the long $19^{\text {th }}$ century extension of corporate power within the space defined as the nation. It was also a vision that shaped the second pivotal moment in the making of the American empire, the postwar/cold war middle decades of the $20^{\text {th }}$ century, when according to Smith, "U.S. global dominance was presented as the natural result of historical progress, implicitly the pinnacle of European civilization, rather than the competitive outcome of political-economic power" (Smith, 2003, p. 20). In other words, Smith suggests that the notion of a "global manifest destiny" that characterized the early $20^{\text {th }}$ century fundamentally shaped America's postwar ascendency as the global hegemon. Similarly, in his comprehensive analysis of the emergence of an international society, Daniel Gorman suggests that the political spaces created through the new international institutions of the 1920s "anticipated the globalized nature of our contemporary world" (Gorman, 2012, p. 318). According to Gorman, the various state and non-state actors involved in the creation of international networks and institutions like the League of Nations and the Carnegie Endowment for International Peace anticipated to a large degree the global agencies of the postwar era such as the United Nations and the Gates Foundation. 
In this paper I draw on these insights into the making of an American empire and the formative nature of the early decades of the $20^{\text {th }}$ century in order to interrogate the international imaginations and national practices of International Harvester as it sought national and international markets in the first two decades of the $20^{\text {th }}$ century. Based on archival research ${ }^{2}$, what I show is that IH, drawing on a dominant discourse of "civilization," imagined its new international markets as the inevitable extension of their national expansion, and the transformations that their products would bring to their new consumers similar to the transformations that those products were bringing to the "backward" farmers living in the United States, particularly African-Americans in the American South. ${ }^{3}$ I also show how their interventions in the American South - through their agricultural extension service - deployed tactics of governance that contributed to the "existing repertoire" and "bricolage" (Li, 2007, p. 6) that became a dominant set of practices of postwar international development. I focus particularly on the ways in which IH's interventions into the US South were framed through what became a common trope of development (Li, 2007; J. C. Scott, 1998): the problematizing of a space/region, and the rendering of its solution as a technical one, in this case the use of agricultural technologies. By so doing, I provide a case study that suggests that the deployment of expert and technological advice practiced by American corporations overseas in the postwar era have their roots in the early $20^{\text {th }}$ century, particularly in the American South. I start by

\footnotetext{
${ }^{2}$ This paper is based on extensive research conducted at the McCormick-International Harvester Collection, Wisconsin Historical Society, Madison, WI., supported by research into the activities of the Agricultural Extension Service of the United States Department of Agriculture undertaken at the National Archives, College Park, MD. ${ }^{3}$ The ways in which the "backward' nature of the American South has been racialized, the implications of this racialization for African-American farmers, and the relationship of both to what was considered the "Negro" problem have been well documented. See for example (Hale, 1998; Johnson, 1934; Moore, 2003; Ring, 2012; Williamson, 1984; Woods, 2000). Although these relationships are clearly important for understanding the contours of American geoeconomic imaginations and practices in the U.S. South, there is not space here to address the issue in more detail. It is important to note that unlike the federal government, International Harvester did not segregate their agricultural extension activities, although this fact should not be taken in any way to reflect their more 'progressive' tendencies.
} 
interrogating the ways in which International Harvester imagined the international as the extension of its national interests, before turning to their interventions into the American South as a sort of practicing ground for later corporate investments in "development."

\section{Imagining the International}

International Harvester was one of the United States' largest international companies, with production facilities located in France, Norway, Canada and Russia, and extensive sales and distribution networks located throughout South America, Asia, Europe and Africa (Carstensen, 1984; Domosh, 2006). As the images from the booklet 100 Harvest Scenes around the World attest, International Harvester was enthusiastic about using this internationalism - providing images of different types of agricultural technology in use around the world -- to promote its products. With its claim that its founder Cyrus McCormick had invented reaping machines, McCormick Farm Machinery Company (the predecessor of International Harvester) often advertised its products through associations with the discourse of "civilization:" reapers and harvester could be used as both signs of and a way of becoming modern and "civilized." The use of this dominant discourse to legitimize sales was not unique to IH (Domosh, 2006; Jacobson, 2001) but its elaboration through the promotion of agricultural technology gave it a particular potency that resonated in later decades (Adas, 2006). As explained by historian Gail Bederman (2008), the discourse of civilization that dominated late $19^{\text {th }}$ and early $20^{\text {th }}$ century American notions of history and geography assumed that the world's people could be sorted by stages that were defined by type of economic activity, degree of gender specialization, and racial categorization. So-called savage peoples lived nomadic lives of hunting and gathering with little 
gender specialization; while so-called civilized peoples were industrialized, white, and segregated by gender such that men occupied the public realm and women the private realm. This discourse was often united with Darwinian notions so that the stages could be seen as evolving from each other, with only the "civilized" races would be seen as totally evolved. This powerful way of understanding history was also transposed onto geography; those portions of the world occupied by "savage” peoples could be seen as representing "civilized" peoples' past. In this way, "other" parts of the world and other peoples could be seen as a distant or not-so-distant past.

The discourse of civilization was easily molded to fit different purposes. As we have seen, associating civilization with "modern" products and with what those products might bring with them became an important advertising tool for many American companies, including International Harvester (Domosh, 2002; Lears, 1995; Rydell, 2013). For example, figure 4 is an advertisement for the company from 1886 that clearly associates agricultural technology with different stages of 'development.' The upper right image depicts 'reapers of the ancient gauls" using primitive techniques; just below it are women gleaners, suggesting (since women are active in the labor force and therefore less gender specialization) a stage of development above the gauls, but not totally civilized. The two images to the left depict modern, civilized men using (of course) McCormick reapers. The middle inset image, of present day India, makes clear the association that India today represents the "gauls" of the past. As discussed earlier, IH used this trope of "other" nations representing the U.S.'s past in many of its ads from this time frame, always making clear however, that "uncivilized" peoples could quickly become civilized with the consumption and use of agricultural machinery, replicating the history of the United States. 
This notion that other portions of the world would be replicating the recent history of the United States - expansion westward, the elimination or relegation of Native Americans to a symbolic past, the creation of a seemingly ever expansive national market - dominated the international imaginations of American economic and political elites in the late $19^{\text {th }}$ and early $20^{\text {th }}$ century (Domosh, 2013). In this way, the expansion of markets for US companies beyond its borders could be seen as a logical extension of its national expansion: just as, for example, the use of agricultural technologies was bringing prosperity to the West of the U.S., it would be providing similar benefits to other regions of the world. This narrative, what I've called elsewhere "frontier narratives in foreign lands" (Domosh, 2006), was embedded in almost all of the IH's advertisements and corporate representations throughout the late $19^{\text {th }}$ and early $20^{\text {th }}$ centuries. A compelling example can be found in figure 5, taken from the company's 1888 catalog. Titled "It's always harvest time with McCormick," the image uses the trope of a monthly calendar to advertise how their machines are in use at all times, but in different spaces, an interesting transposition of time and space. In January, for example, "The McCormick is moving ahead in Australia and New Zealand," while in July "The McCormick is busy in Illinois, Iowa, Missouri, Maryland, Indiana, Nebraska, Colorado, Utah. Wisconsin, New York, Ohio, Michigan, France, Austria, Russia and Asia.” Foreign lands, therefore, are presented as little different from national ones; as places where, as the title of the newspaper that is being read by the farmer suggest, the "farmers advance" is made possible by new technologies. And just as the Native Americans were often used by IH and other companies to represent the past, the small vignette in the upper left of the image suggests that "primitive" Native New Zealanders (noted as such by their relative lack of clothing and the apparent arrow) will soon disappear or become vestiges of the past, as the course of agricultural machinery continues across the landscape, 
moving away from him. This reading of the international through the lens of the national, and the trope of picturing the course of 'civilization' as stages in the use of agricultural technology, continued to dominate IH's advertisements and promotional material throughout the early $20^{\text {th }}$ century. By 1913, when the company produced 100 Harvest Scenes Around the World, most of its customers would have been well acquainted with the company's global reach and the ways that its products were purportedly bringing modernity and "civilization" to Africa, Asia and South America, just as it had brought prosperity to the American farmer.

Agricultural Extension, International Harvester, and the American South

In late 1912 and early 1913, just as the booklet was being produced and published, International Harvester established its division of agricultural extension and set out to put into action what hitherto fore it had only imagined: the transformation of "primitive" farmers into modern ones through the use of agricultural technology ("Report of Service Bureau meeting held in Mr. Owing's office this morning at 8:30 a.m.," 1912). And the obvious first choices of subjects to be modernized were those American farmers still using, as the caption of figure 3 indicates, "primitive methods" - the "miserably poor colored people of the south." IH's attempts to "improve" farming methods in the United States were coincident with a much larger effort (in both scope and scale) by the United States Department of Agriculture to provide outreach to American farmers. Historian Roy Scott (1970) details the diverse activities undertaken by communities, private concerns, and local governments aimed at helping farmers become more productive in the United States, activities that ranged from farmers' granges and governmentsponsored educational activities in the $19^{\text {th }}$ century, to farmers' institutes, demonstration farms, 
and federally-funded university courses and outreach in the early $20^{\text {th }}$ century. The federal government's investments in agricultural extension were predicated both on the historical importance of agriculture and 'productive' farmers to the economy of the country, and on their ideological importance as symbols of a robust and productive nation (Smith 1970; Scott 1970). By the turn of the $20^{\text {th }}$ century, farming was seen as lagging behind the scientific and technological achievements witnessed in other sectors of the US economy, prompting a renewed set of investments geared at 'modernizing' the famer. Teddy Roosevelt's Country Life Commission in 1908 called for improvements in rural schooling, health, and infrastructure and created public interest in the establishment of an agricultural extension service (Ellsworth, 1960; Peters \& Morgan, 2004). With the passage of the Smith-Lever Act in 1914, many of these various extension activities were centralized with federal support, formalizing an alliance between the Department of Agriculture and land-grant universities to provide practical and scientific instruction to farmers and farm families (Kloppenburg, 1988; McDowell, 2001; R. V. Scott, 1970). In other words, the goals of the extensive public investments in agricultural extension were to create better farmers and citizens through the application of formalized agricultural instruction.

International Harvester became actively involved in these efforts in 1910 when it established its service bureau, a division of the advertising department dedicated to providing agricultural advice to farmers (Cooley, 1922). Two years later, in 1912, the company hired Professor Perry Holden, a renowned agronomist and former head of agricultural extension at Iowa State University, to oversee the bureau, and the division was moved out of the advertising department into its own division and renamed the agricultural extension department; both moves working to secure scientific acumen and legitimacy to its extension efforts ("Report of Service 
Bureau meeting held in Mr. Owing's office this morning at 8:30 a.m.," 1912). These efforts were wide-ranging, from publishing guides to better farming, to sending experts on "campaigns' to deliver lectures to farmers. According to the company, all of these activities were purely educational in purpose. An article in their corporate newsletter states: "The work of the extension department is entirely educational. Increasing production and eliminating waste on the farm; improving living conditions in town and country; making the farmer more prosperous; making housework easier for the farmer's wife; safeguarding the health in the farmer's family; creating within the farm boy and girl a lasting love for the farm and a greater interest in agriculture" (Cooley, 1922, p. 7). But the company was of course well aware of the potential profits that would follow from the 'education' of farmers. Near the end of the very same newsletter article (and interestingly deleted in the final copyedited version), Edgar Cooley lists the benefits of the extension service activities for the company, focusing on the increased purchasing power that follows greater agricultural productivity, particularly the increased sales caused by promoting the diversification of farming: "When a farmer grows nothing but wheat or cotton or tobacco, the number and variety of implements he needs is very limited. When [diversification occurs] he needs a large number of implements for which he had not previous use" (Cooley, 1922, p. 10).

So even though it was not meant to be explicit, IH's agricultural educational activities were indeed part of the company's advertising campaigns. What was "new" is that they would be putting into practice what previously had only been implied through their visual and verbal advertisements. Unable to intervene in the lives of farmers living in other countries, $\mathrm{IH}$ executives were eager to show the "civilizing" and modernizing effects of agricultural technology by providing expert advice and selling farm machinery in portions of the United 
States considered not quite modern. And as figure 3 makes clear, the U.S. South figured prominently in this regard. ${ }^{4}$ International Harvester was not alone in this; the United States Department of Agriculture also focused its efforts on the South. Although agricultural extension was nationwide, and was formalized as such in 1914 (via the Smith-Lever act), the American south served a critical role in the early 'practicing' of many of these extension activities, particularly the establishment of demonstration farms (R. V. Scott, 1970). Scott outlines the various reasons why the South was, in his words, "more than any other region, in need of rural rejuvenation" (206). The reasons included poor farming methods ("one-horse farming, shallow plowing, inadequate seed-bed preparation, defective drainage" (206)), in addition to a classed and raced socio-economic system and a history of sharecropping and crop-lien systems. According to historian Natalie Ring (2012), early $20^{\text {th }}$ century agricultural and social reformers "believed the South posed the most complex of problems" (122) and those problems challenged the modernity of the entire nation. The U.S. South had long been considered an exceptional region that functioned somehow outside the norms of American society and economy (Giesen, 2012; Jansson, 2010; Ring, 2012; Strom, 2010; Winders, 2003, 2005; Zimmerman, 2010) -- "not quite a nation within a nation, but the next thing to it" (Cash, 1991, p. viii). And the reconstruction efforts after the Civil War had set precedents for northern interventions meant to reshape the South's socio-economic structure so as to fit Northern norms. It is not surprising, then, that interventions intended to modernize farming also focused on the South, particularly in the Black Belt, a term used to denote a region of rich soils that stretched from the central areas of

\footnotetext{
${ }^{4}$ The other "problem" region for IH and for the USDA was the West, particularly the Great Plains, where periodic droughts were causing many experts to wonder if grain farming was sustainable. But those "problems" were never imagined as signs of primitiveness or representative of a past time. Instead the region was always imagined in the future tense; as a signifier of what agricultural technology and modernity were about to bring to the nation. See Scott 1970.
} 
the Carolinas to central Arkansas and that shared a history of plantation agriculture focused on cotton.

During the first three decades of the $20^{\text {th }}$ century, IH's service bureau organized a series of major 'campaigns' that involved sending their agricultural experts to Alabama, Mississippi, and Arkansas, lecturing in town meeting halls and churches, distributing educational materials produced by the company, meeting with local dignitaries, and generally spreading the "good" word about how International Harvester's products and experts could improve agriculture and living conditions (see figure 6). In addition, the company established three demonstration farms in the South (one each in Mississippi, Alabama, and Georgia) in order to "promote the cause of better farming" (Alford 1914, p. 5), published a series of educational booklets outlining strategies for everything from better farming techniques to home canning, and produced a series of photographs documenting the activities of their experts and the 'subjects' of their advice (as in figure 1). They did so because, as company representatives wrote, the South presented "the picture of gloom" (Wood \& Wood, 1918, p. 4). In other words, they presented Southern agriculture as in a state of "crisis."

\section{Creating the Crisis}

In The Will to Improve: Governmentality, Development and the Practice of Politics Tanya Li (2007) writes convincingly of the ways in which, throughout much of the $20^{\text {th }}$ century, Indonesia was made into a "problem" that required Western-inspired, technical solutions. In this way, development schemes of "improvement" came to be seen as benevolent and inevitable. Similarly, the South and particularly Southern agriculture was often seen by Northern experts as 
in a state of crisis in the first decades of the $20^{\text {th }}$ century, a crisis marked by the apparent poverty and malnutrition of its farmers, but one that could only be fixed by "rendering technical" ( $\mathrm{Li}$, 2007, p. 7) what was in fact socio-political: the continuation of the plantation system and the disenfranchisement of African-Americans particularly in the cotton belt of the South (Giesen, 2012; Johnson, 1934; Wiener, 1978; Woods, 2000). International Harvester's extension service participated actively in the problematizing of Southern agriculture and in rendering technical its possible solutions. The experts hired by International Harvester - particularly Perry Holden focused on two interrelated aspects of Southern agriculture that were considered exceptionally challenging: diseases and an over-reliance on cotton.

That the South was seen as a diseased region was not something specific to International Harvester or agricultural extension efforts in general. Scholars have documented the making of the South as an unhealthy region, tracing its roots from the association of tropical climates and disease of the $18^{\text {th }}$ and $19^{\text {th }}$ centuries to the beginning of public health efforts to eradicate hookworm (Birn, 2006; Farley, 2004; Giesen, 2012; Ring, 2012). In terms of agriculture the concern focused on cattle tick fever, a tick-borne disease that if left untreated weakened and could kill cattle, and the boll weevil, a small beetle that feeds on cotton buds and flowers. Originating in Mexico, the boll weevil spread into the United States in the late $19^{\text {th }}$ century and had infested large areas of the cotton belt. Both of these diseases were considered manageable if the correct scientific farming techniques were used, techniques that the IH experts were meant to share with farmers. Two of the nine chapters in one of IH's service bureau's first publications (1913) - For Better Crops in the South - are dedicated to discussions of the causes and techniques for handling these two diseases. In "Texas Fever Tick" Dr. Mark Francis provides an overview of how the disease is spread from the tick to cattle, what happens to the cattle when 
they contract the illness, detailed instructions about how to introduce healthy northern cattle into the South through inoculations ("a compilation of the work done by the Southern experiment stations shows that by this plan of treatment and management it is quite easy to save over 90 per cent of Northern cattle" (Francis, 1913, pp. 67-8)), and how best to deal with the disease once contracted through constructing and then dipping cattle into a large vat filled with an arsenic mixture that would kill most of the ticks. Graphic images of tick infestations, photographs comparing sick cattle with healthy ones, and charts and tables outlining how to build a dipping vat and what chemicals to put in it enrich, the "advice". These striking visual "object lessons" in regard to the crisis caused by the tick are repeated in the series of photographs taken by the company during their "campaigns" as fig. 7 shows. Here, Holden himself is depicted with a lecture chart comparing, through maps, the work done in cattle tick eradication in Mississippi from 1912 to 1914 with that of Alabama, and exhorting the farmers to "make Alabama tickless."

Similar graphic evidence of the impact of disease on southern agriculture illustrate the chapter on the boll weevil (Alford, 1913) in which George Alford exhorts southern farmers to destroy the weevil by eliminating its food supply (parts of the cotton foliage) and by planting early-maturing cotton. Alford, a former USDA employee working in agricultural extension in Southern Mississippi, was one of the few "experts" from the South; he was hired by Holden to be in charge of the extension service's southern division. The exhortations are repeated with more detail in the longer pamphlet he wrote the following year called How to Prosper in Boll Weevil Country, where Alford presents the "results of many experiments conducted" (Alford, 1914b, p. 13) in regard to boll weevil reduction, although here he adds a third element to that reduction: less reliance on cotton farming. With Holden in charge, a firm believer that scientific farming would solve all problems including the boll weevil infestation, Alford argues that providing 
"proper" methods of cotton cultivation will allow for land to be used for other farming needs:

"many farmers in the boll weevil territory are now producing as much cotton on five acres by

following proper methods as they formerly produced on ten acres, thus leaving half of their land to produce some other crop." And in his booklet published the same year (1914) called

Diversified Farming in the Cotton Belt, Alford refers to the boll weevil as a "grave crisis" that is of "paramount importance to cotton farmers" but here only mentions diversified farming as the purported solution: "only one rational method of meeting this loss presents itself and that method is the diversification of crops" (Alford, 1914a, p. 17). An over-reliance on cotton is the cause of Southern poverty, according to Alford: "The too exclusive culture of cotton has exhausted the hummus, the life-giving principle in our soils; the washing of the clean cotton fields has gone on to such an extent that millions of acres of the best lands in the Cotton Belt have been made nonproductive" (Alford, 1914a, p. 3). A photograph taken by the company in Mississippi provides striking visual accompaniment to this statement (fig. 8). The original figure caption leaves little to the imagination in terms of explaining what has caused this devastation: "this field - an abandoned Cotton field near Meridian, Miss. shows how many thousands of acres of good Southern land have been ruined by one crop farming. Year after year the field was planted in cotton and after the cotton was taken off, it was let lay all winter with no protecting crop, or pasture, from the heavy dashing rains of the South, during the winter season, and as a consequence, the fertility of the soil has been literally washed away."

As historian James Giesen (2012) has shown, the boll weevil infestation and the so-called crisis it created was used by the USDA and other agricultural experts as a way of convincing southern farmers to adopt "scientific" methods of farming and to move away from their reliance on cotton. His analysis points to the ways that particular groups of people had vested interests in 
creating the boll weevil crisis and then in "solving" it with "modern" methods brought from the North. USDA bureaucrats and experts "saw in the pest a solution to the South's overdependence on cotton and a way to overcome farmers' unwillingness to employ modern, scientific farming methods" (Giesen, 2012, p. 2). And corporations like International Harvester were clear partners in this: a disease caused a crisis, and the crisis could only be overcome with the adoption of modern methods of farming.

A booklet published by the company in 1915 reporting on their recent "campaigns" primarily in the South provides a good accounting of the company's goals. Thirty years before Truman's inaugural address outlining the provisioning of food as the world's largest problem, IH opened its booklet "We Must Feed Ourselves" with the line "The world's greatest economic problem leads to the Farm" (We Must Feed Ourselves, 1915, p. 1). And in the American south, the "problem" was an over reliance on cotton. According to the booklet, Arkansas' 1913 cotton crop sold for $\$ 63,000,000$, but an additional $\$ 12,000,000$ more was spent out of state to buy foodstuffs. In order to help make Arkansas more self-sufficient and diversify its agricultural system, "many prominent interests invited Professor P.G. Holden of the Agricultural Extension department of the IHC to come to Arkansas and direct a state-wide agricultural campaign." This campaign had as its purpose "to impress on the people the necessity of making Arkansas farms feed Arkansas people; to have something to sell every week in the year and keep the proceeds of the cotton crop at home; to get rid of the cattle tick; have more pastures; grow cattle, hogs, poultry, and to have a garden for every home; to have good schools; good roads; and a million new people to occupy the farms and cities of Arkansas" (We Must Feed Ourselves, 1915, p. 5). Accordingly, IH sent 30 men in November of 1915 who conducted 1,324 meetings in 49 different counties over 35 days (IH loved to keep statistics of these events, signs of 
"modernity"), covering the cotton belt of the state, with 130,000 people attending the meetings. C.C. Kirkpatrick, one of the members of the campaign, wrote of the results: "cotton acreage" he says, "has been reduced 15 to $20 \%$ for 1915 and food crops have been planted on these acres." In addition, he wrote, all but 18 of the state's 75 counties have "declared for Tick Eradication; and more gardens have been planted this year in Arkansas than ever before in the history of the state" (We Must Feed Ourselves, 1915, p. 6). Their Alabama campaign also lasted 35 days, with a similar focus to Arkansas: "Alabama's prosperity lies in the eradication of the cattle tick; in cattle, hogs, and poultry; in growing legume crops and maintaining pastures of Bermuda and other grasses; in having a garden for every home" [emphasis in original](We Must Feed Ourselves, 1915, p. 10).

\section{Solving the Crisis}

According to Holden and International Harvester, the key to solving the problems of southern agriculture - problems brought on through disease and an over reliance on cotton - was the diversification of agriculture. They called their campaign in Alabama in 1915 "The Alabama Crop Diversification Campaign" and figure 9, with the caption "Professor Clark explaining the possibilities of diversified farming to a group of farmers at New Home School" depicts the lecture charts used in this regard. The three demonstration farms that they established in the South were meant to "aid in bringing to the cotton belt the same measure of substantial prosperity that diversified farming has brought to the corn belt of the North" ("Southland Chosen for new Demonstration Farm," 1921, p. 15). Alford writes that the object of opening these farms in the South was "to promote the cause of better farming" (5) through the use of "a systematic 
rotation of crops" (Alford, 1914c, p. 14). As he writes of the Brookhaven farm in Mississippi, "we are changing a gullied cotton farm into a profitable dairy and diversified farm . practically all of the feed for man is now grown upon the farm" (Alford, 1914c, p. 6). And the pamphlets that they published - with titles that ranged from "Diversified Farming in the Cotton Belt," "For Better Corn in the Cotton Belt," and "Getting a Start with Alfalfa in the Cotton Belt" -- were filled with admonitions about why diversified farming was better than a reliance on cotton, and advice about how best to diversify. The company repeated its solution of diversified farming for the "problems" of farming in the South throughout the teens and twenties. L.A. Hawkins writing in 1929 in regard to "Better Pastures in the South" suggests that the "right methods of pasture management" can help diversify Southern farming and help solve the problem of an overreliance on cotton. (p. 10).

If diversification was a solution to the problems of southern agriculture, both in terms of shifting agriculture away from a reliance on cotton, and by helping to eliminate the devastation caused by the boll weevil, the key to diversification was the adoption of scientific farming practices and the use of modern machinery. Alford advocated for the "value of a proper system of crop rotation," that is "based on scientific experiments" in order to diversify the South, assuring farmers that "under this modern system of farming some of our acres will not be needed for cotton," and "under these advanced methods, the soil will rapidly increase in fertility" (Alford, 1914a, p. 7). He also addressed the local business community, arguing that solving the farming "crisis" requires a community response:

Every corporation and business man interested in the welfare of the country, should join forces with the USDA, Agricultural Colleges, Experiment Stations. State Departments of Agriculture and other forces and conduct great Educational Campaigns until the foolish and criminal wastes that are going on every year by reason of unscientific methods of farming is a thing of the past. (Alford, 1914a, p. 43) 
Ridding the South of the "foolish and criminal wastes" through educational campaigns is exactly, of course, what International Harvester proclaimed to be doing. They were also promoting the use of machinery. Alford's discussion of diversification is littered with references to the benefits of modern farming equipment. In his discussion of how to properly grow corn in the South, he explains how "modern machinery has greatly lessened the labor of cutting and shucking the corn" (Alford, 1914a, p. 32). And, perhaps most telling, he proclaims that "probably the chief cause of poverty in the South is the one-horse plow" (Alford, 1914a, p. 34) and provides two photographs that leave little doubt about the promise of technology (see fig. 10).

Similarly, in his chapter "Corn Culture in the South," J. Oscar Morgan wrote "Corn requires a deep soil, which means deep plowing. The one-horse plow has been too commonly used in preparing land for corn and as a result Southern soils, as a rule, are not deep enough" (Morgan, 1913, p. 10). He continues with more prompting to use proper equipment: "Harrows are not used enough in the South. The disk harrow, the spring-tooth harrow and the spike-tooth harrow are excellent implements for working the soil into a good seed bed after it is plowed" (Morgan, 1913, p. 10). Later, in regard to harvesting corn, he writes "The practices so common in the South, of stripping the blades from the corn plans for 'fodder' or of cutting the tops just above the ear, are too wasteful of time and grain to warrant their use ... carefully conducted experiments have demonstrated that when the corn crop is thus handled, at least three bushels of grain per acre are lost, besides, it is a slow operation" (Morgan, 1913, p. 13). In the same edited collection, Cyril Hopkins (1913) provides an overview of the issue of soil fertility in general, without focusing on the South. However, images are inserted into the text that are not directly relevant to the discussion: one set of photographs compares what it calls in the caption "The old inefficient way of spreading manure" (with the use of a pitchfork by hand) with three images of 
men using automated manure spreaders, with the captions: "saving labor and getting the best out of the manure," "a uniform application of manure insures better returns," and "manure spread evenly is most valuable." Each of these images make clear that machines do a far superior job at spreading manure on the fields - thereby fertilizing them - than could be done by hand.

So the solution to the problems of Southern agriculture and poverty was the purchase and use of agricultural machinery, not a particularly surprising conclusion from a company that produced that machinery. But it is not an obvious conclusion. The company repeatedly and continually spoke of its agricultural extension department as a "service to humanity" (Cooley, 1922, p. 7), and no doubt many of its executives and employees believed that to be true, as did of course the many farmers who benefitted from their advice and information. And the "solution" wasn't unique to IH; many Northern elites who provided guidance to the USDA cooperative extension agency also recommended diversification as one of the keys to solving what was considered the problem of Southern agriculture, and modern machinery as key to the future prosperity of southern farmers (Giesen, 2012; Ring, 2012; R. V. Scott, 1970; Strom, 2010). Alford includes an extensive quote from Seaman Knapp (an early advocate of "modern" farming techniques in the South, considered the "father" of extension work on the part of the U.S. government) from an address that Knapp gave in Mississippi, and the quote reflects what many northern elite and the USDA believed:

The farmer who uses modern machinery in planting and cultivating his crop will succeed, and the one who does not will make a failure. The old way of making a crop by hand by the use of the hoe and plow must soon be a thing of the past. We must come to use the modern implements and the sooner we let the negro understand that he must work his crop in this way, the better off we shall be. (Alford, 1914b, p. 24)

Mechanization, he emphasizes, is the key to agricultural success; manual labor is a thing of the past. Here we see an interesting conflation of the non-modern, the past, and the "negro," 
echoing what International Harvester's advertising schemes had suggested about India and Egypt (see figs 2 and 4). Knapp, giving voice to what many northern elites imagined about the state of southern agriculture, saw the "negro" and his way of life as a soon-to-be vestige of the past, replaced by modern technologies and "better" farming. As we have seen here, International Harvester shared a similar view, and given their experiences establishing factories outside the United States and developing sales networks throughout much of the world, the "foreign" figured prominently in their imaginations of the past, and therefore of the South. Figure 11 provides an important comparison. Taken around 1917, the photograph echoes in many ways those taken of African-American men and women in the South, using, in IH's words, primitive methods of plowing. The original caption of this image reads "Primitive methods of agriculture in Russia (Volga region)."

This transposition of the foreign and the national, and of the Southern "negro" for the foreign "peasant" permeates much of the imaginative conceptions of $\mathrm{IH}$, as I have shown particularly through the set of photographs the company produced in the early decades of the $20^{\text {th }}$ century. The degree to which they could translate that imagination into practices of intervention was of course much more limited. Throughout the first half of the $20^{\text {th }}$ century IH continued to expand their production and sales operations internationally with only relatively minor disruptions due to wars and revolutions (Carstensen, 1984; Domosh, 2010). But with little if any geopolitical power, and therefore no control over the types of networks that would have been necessary in order to conduct agricultural extension work, $\mathrm{IH}$ was unable to actively intervene into "modernizing" peoples outside the United States. ${ }^{5}$ In Russia, for example, one of

\footnotetext{
${ }^{5}$ International Harvester relied on a supply of twine for its binders from sisal grown in the Yucatan region of Mexico and in the Philippines, and therefore maintained large production facilities in both places. In the Philippines, of course, that supply and the disciplining of workers that made the supply available, could be ensured
} 
International Harvester's largest markets, evidence suggests that they tried to establish demonstration farms in certain regions, but those activities were very limited. A photograph taken of one of these demonstration farms is telling not necessarily because of the image, but because of the original caption it was given: "Holdenizing South Russia. At the right is the corn that the boys shown in No. 1 tested - planted according to the peasant custom. These fields were plowed at the same time and planted on the same day. We have 120 demonstrations plots like this on which more than a thousand boys are learning to grow five ears of corn where only one grew before." Clearly, then, IH was transferring some of its activities that they had practiced in the U.S. South to South Russia, "Holdenizing" it with new technology and making object lessons of the inferiority of "peasant" custom. The image is dated 1917, and even though not all of IH's activities in Russia came to a halt immediately after the Bolshevik revolution (Carstensen, 1984; Domosh, 2006, 2010), any large-scale attempt at "modernizing" Russian agriculture by foreign companies ended. This did not stop the company, however, from boasting about its commitment to educating farmers world-wide, and from claiming that that education was a welcome intervention. In its summary of its service work in 1922, Cooley wrote, "in one way or another the department has been helpful to farmers and town dwellers in every state of the Unions, Alaska, Hawaii, the Philippines, Canada, Mexico, Peru, Argentine, Porto Rico, Holland, Russia and China, and many islands of the seas, and it is pleasing to know that the work has had the enthusiastic approval of hundreds of thousands of people in all walks of life, in all parts of the American and in foreign lands" (Cooley, 1922, p. 7). 


\section{Conclusion}

Even though International Harvester never actualized that rhetoric, the internationalist goals and practices embedded in it express much about how American economic elites were envisioning what came to be called the American century. As I have shown here, corporate leaders imagined the expansion of their markets beyond U.S. borders as an extension of the expansion within those borders, with the transformative potential of their products - turning "primitive" peoples into "modern" ones - remaining constant and made to seem inevitable from the regional to the national to the international scale. IH operationalized that imaginative conception in their agricultural extension services in the American South, turning "primitive" farmers into modern ones through the purchase and use of technology, thereby "solving" the problem of Southern agriculture. And they were not alone in doing so. Under the guise of agricultural modernization, the US federal government, in addition to other corporations and philanthropies, trained "experts" to help solve the "problems" of agriculture in the United States, particularly in the South (Giesen, 2012; McDowell, 2001; Ring, 2012).

It would take another thirty years before the US government began any active intervention into the agricultural systems of other countries, beginning in the immediate post World War II years with the establishment of agricultural experiment stations overseas and then formalizing activities under the aegis of USAID (Rist, 2008; Staples, 2006). By then International Harvester's overseas sales were focused primarily on trucks and tractors, and their involvement in educational or extension work (both domestically and overseas) was curtailed. Meanwhile the Rockefeller Foundation, building on its hookworm eradication schemes in the U.S. South, continued its interventions in Mexico around health and agriculture, eventually, in 
collaborations with Ford Foundation and US biotechnology companies, developing new hybridized seeds that after being "tested" in Mexican fields became the cornerstone technologies of the Green Revolution (Birn, 2006; Perkins, 1997). Reported as the great 'services to humanity,' these new technologies failed to rid the world of hunger, but they did serve as weapons in the Cold War and as sources of profit for American companies such as Monsanto (Cullather, 2004; Shiva, 1992). International Harvester's agricultural extension service activities in the South may not have led to great material effects in terms of decreasing Southern poverty, but its images of and activities in the U.S. South did provide useful models for what other corporations would do in later years, forming part of the "existing repertoire, a matter of habit, accretion, and bricolage" (Li, 2007, p. 6) that shapes programs of intervention. Its imaginative intertwining of the international and the national, of the "peasant" with the "negro," and its legitimization of advertisement as "education" and increased sales as "improvement," suggest that IH's agricultural extension activities in the U.S. South was an early and important site in the genealogy of American international development practices. Although I recognize that the genealogy that I have presented here is partial and limited, I hope it will prompt other explorations into the ways that US corporations began to intervene in the making of "modernity" overseas thus contributing to historical geographies of American empire.

\section{References}

Adas, M. (2006). Dominance by design: Technological imperatives and America's civilizing mission. Harvard University Press. 
Alford, G. (1913). How to Grow Cotton in Spite of the Boll Weevil. In For Better Crops in the South (pp. 34-42). International Harvester Company of America Service Bureau.

Alford, G. (1914a). Diversified Farming in the Cotton Belt. International Harvester Company of New Jersey Agricultural Extension Division.

Alford, G. (1914b). How to Prosper in Boll Weevil Territory. International Harvester Company of New Jersey Agricultural Extension Division.

Alford, G. (1914c). Southern I-H-C Demonstration Farms. International Harvester Company of New Jersey Agricultural Extension Division.

Anderson, P. (2002). Internationalism: A Breviary. New Left Review, 14, 5-15.

Bederman, G. (2008). Manliness and civilization: A cultural history of gender and race in the United States, 1880-1917. University of Chicago Press.

Birn, A.-E. (2006). Marriage of Convenience: Rockefeller International Health and Revolutionary Mexico. Rochester, NY: University of Rochester Press.

Burke, T. (1996). Lifebuoy Men, Lux Women: Commodification, Consumption, and Cleanliness in Modern Zimbabwe. Durham, NC: Duke University Press.

Carstensen, F. V. (1984). American enterprise in foreign markets: Studies of Singer and International Harvester in imperial Russia. UNC Press Books.

Cash, W. J. (1991). Mind of the South. New York City: Vintage Books.

Cooley, E. (1922, October). The Company's Progress in its Human Relations. The Harvester World, 13(910), 7-15.

Cowen, D., \& Smith, N. (2009). After geopolitics? From the geopolitical social to geoeconomics. Antipode, 41(1), 22-48.

Cullather, N. (2004). Miracles of Modernization: The Green Revolution and the Apotheosis of Technology. Diplomatic History, 28(2), 227-254. 
Domosh, M. (2002). A "civilized"commerce: gender,"race", and empire at the 1893 Chicago Exposition. Cultural Geographies, 9(2), 181-201.

Domosh, M. (2006). American Commodities in an Age of Empire. New York City: Routledge.

Domosh, M. (2010). Uncovering the Friction of Globalization: American Commercial Embeddedness and Landscape in Revolutionary-Era Russia. Annals of the Association of American Geographers, 100(2), 427-443.

Domosh, M. (2013). Geoeconomic Imaginations and Economic Geography in the Early Twentieth Century. Annals of the Association of American Geographers, 103(4), 944-966.

Ellsworth, C. S. (1960). Theodore Roosevelt's Country Life Commission. Agricultural History, 34(4), 155172.

Farley, J. (2004). To Cast out Disease: A History of the International Health Division of the Rockefeller Foundation (1913-1951). New York, NY: Oxford University Press.

Francis, M. (1913). Texas Fever Tick. In For Better Crops in the South (pp. 64-73). International Harvester Company of America Service Bureau.

Giesen, J. C. (2012). Boll weevil blues: cotton, myth, and power in the American South. University of Chicago Press.

Gorman, D. (2012). The Emergence of International Society in the 1920s. Cambridge University Press.

Hale, G. E. (1998). Making Whiteness: The Culture of Segregation in the South, 1890-1940. New York: Knopf Doubleday Publishing Group.

Hopkins, C. G. (1913). Increasing Soil Fertility. In For Better Crops in the South (pp. 14-33). International Harvester Company of America Service Bureau.

International Harvester Corporation. (1913). Harvest Scenes Around the World.

Jacobson, M. F. (2001). Barbarian virtues: The United States encounters foreign peoples at home and abroad, 1876-1917. New York: Macmillan. 
Jansson, D. (2010). Racialization and "Southern" Identities of Resistance: A Psychogeography of Internal Orientalism in the U.S. Annals of the Association of American Geographers, 100, 202-221.

Johnson, C. S. (1934). Shadow of the Plantation. Chicago, Illinois: The University of Chicago Press.

Kloppenburg, J. (1988). Seeds and sovereignty: The use and control of plant genetic resources. Durham, NC: Duke University Press.

Laird, P. W. (1998). Advertising Progress: American Business and the Rise of Consumer Marketing. Baltimore: The Johns Hopkins University Press.

Lears, J. (1994). Fables of Abundance: A Cultural History of Advertising in America. New York, NY: Basic Books.

Lears, J. (1995). Fables of abundance: A cultural history of advertising in America. Basic Books.

Li, T. M. (2007). The will to improve: Governmentality, development, and the practice of politics. Durham, NC: Duke University Press.

Malkki, L. (1994). Citizens of Humanity: Internationalism and the Imagined Community of Nations. Diaspora: A Journal of Transnational Studies, 3(1), 41-68. doi:10.1353/dsp.1994.0013

Massey, D. (2005). For space. Sage.

McClintock, A. (2013). Imperial leather: Race, gender, and sexuality in the colonial contest. New York: Routledge.

McDowell, G. (2001). Land-Grant Universities and Extension into the 21st Century. Ames, lowa: lowa University Press.

Moore, J. M. (2003). Booker T. Washington, W.E.B. Du Bois, and the Struggle for Racial Uplift. Rowman \& Littlefield.

Morgan, J. O. (1913). Corn Culture in the South. In For Better Crops in the South (pp. 5-13). International Harvester Company of America Service Bureau.

Perkins, J. H. (1997). Geopolitics and the green revolution. New York: Oxford University Press. 
Peters, S., \& Morgan, P. (2004). The Country Life Commission: Reconsidering a Milestone in American Agricultural History. Agricultural History, 78(3), 289-316.

Report of Service Bureau meeting held in Mr. Owing's office this morning at 8:30 a.m. (1912, November 25). Unpublished manuscript, Wisconsin Historical Society, Madison WI.

Ring, N. (2012). The Problem South: Region, Empire, and the New Liberal State, 1880-1930. Athens, GA: University of Georgia Press.

Rist, G. (2008). The history of development: from Western origins to global faith. London; New York: Zed. Rosenberg, E. (2011). Spreading the American dream: American economic and cultural expansion, 18901945. New York: Macmillan.

Rydell, R. W. (2013). All the world's a fair: Visions of empire at American international expositions, 18761916. Chicago: University of Chicago Press.

Schulten, S. (2001). The geographical imagination in America, 1880-1950. Chicago: University of Chicago Press.

Scott, J. C. (1998). Seeing like a state: How certain schemes to improve the human condition have failed. New Haven: Yale University Press.

Scott, R. V. (1970). The reluctant farmer: The rise of Agricultural Extension to 1914. Urbana, IL: University of Illinois Press.

Shiva, V. (1992). The Violence of Green Revolution: Third World Agriculture, Ecology, and Politics. New York, NY: Zed Books.

Smith, N. (2003). American empire: Roosevelt's geographer and the prelude to globalization. Berkeley: Univ of California Press.

Southland Chosen for new Demonstration Farm. (1921). The Harvester World, 14(8), 15.

Sparke, M. (1998). From geopolitics to geoeconomics: Transnational state effects in the borderlands. Geopolitics, 3(2), 62-98. 
Sparke, M. (2007). Geopolitical fears, geoeconomic hopes, and the responsibilities of geography. Annals of the Association of American Geographers, 97(2), 338-349.

Staples, A. L. S. (2006). The Birth of Development: How the World Bank, Food and Agriculture Organization, and World Health Organization Changed the World, 1945-65. Kent, Ohio: The Kent State University Press.

Strom, C. (2010). Making Catfish Bait out of Government Boys: The Fight Against cattle Ticks and the Transformation of the Yeoman South. Athens, GA: University of Georgia Press.

The Story of Twine. (1912). Chicago: International Harvester Company of America.

Wells, A. (1985). Yucatan's Gilded Age: Haciendas, Henequen, and International Harvester, 1860-1915. Albuquerque: University of New Mexico Press.

We Must Feed Ourselves. (1915). International Harvester Company of New Jersey Agricultural Extension Division.

Wiener, J. M. (1978). Social Origins of the New South, Alabama, 1860-1885. Baton Rouge, LA: Lousisana State University Press.

Williamson, J. (1984). The Crucible of Race: Black-White Relations in the American South since Emancipation. New York: Oxford University Press.

Winders, J. (2003). White in all the wrong places: white rural poverty in the postbellum US South. Cultural Geographies, 10(1), 45-63.

Winders, J. (2005). Imperfectly imperial: Northern travel writers in the postbellum US South, 1865-1880. Annals of the Association of American Geographers, 95(2), 391-410.

Woods, C. (2000). Development Arrested: The Blues and Plantation power in the Mississippi Delta. New York, NY: Verso.

Wood, W. K., \& Wood, W. L. (1918). For Permanent Agriculture in the South. International Harvester Company Incorporated Agricultural Extension Department. 
Zimmerman, A. (2010). Alabama in Africa: Booker T. Washington, the German empire, and the globalization of the New South. Princeton, NJ: Princeton University Press. 


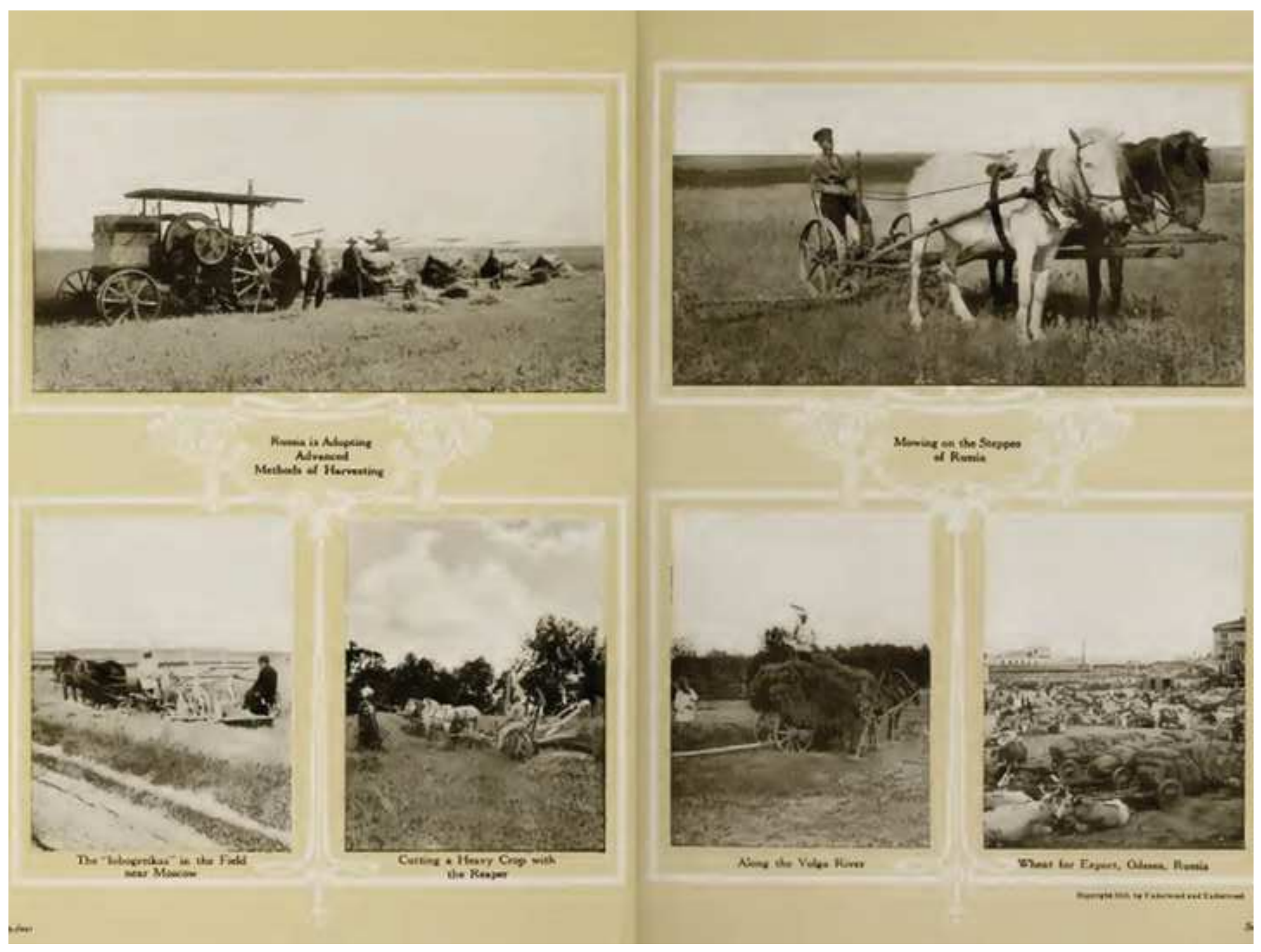

Mroug on the Seerese

Mtreced 


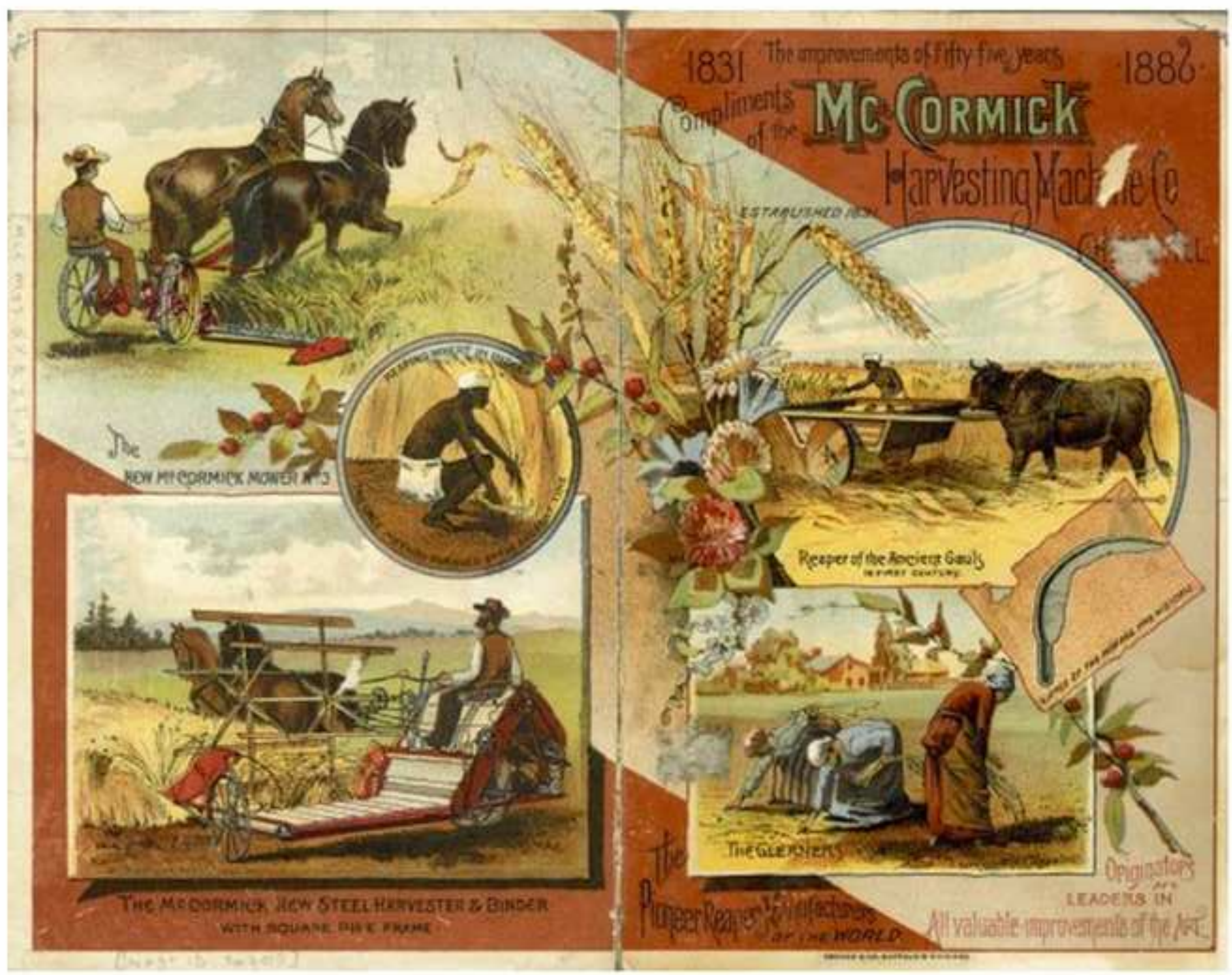




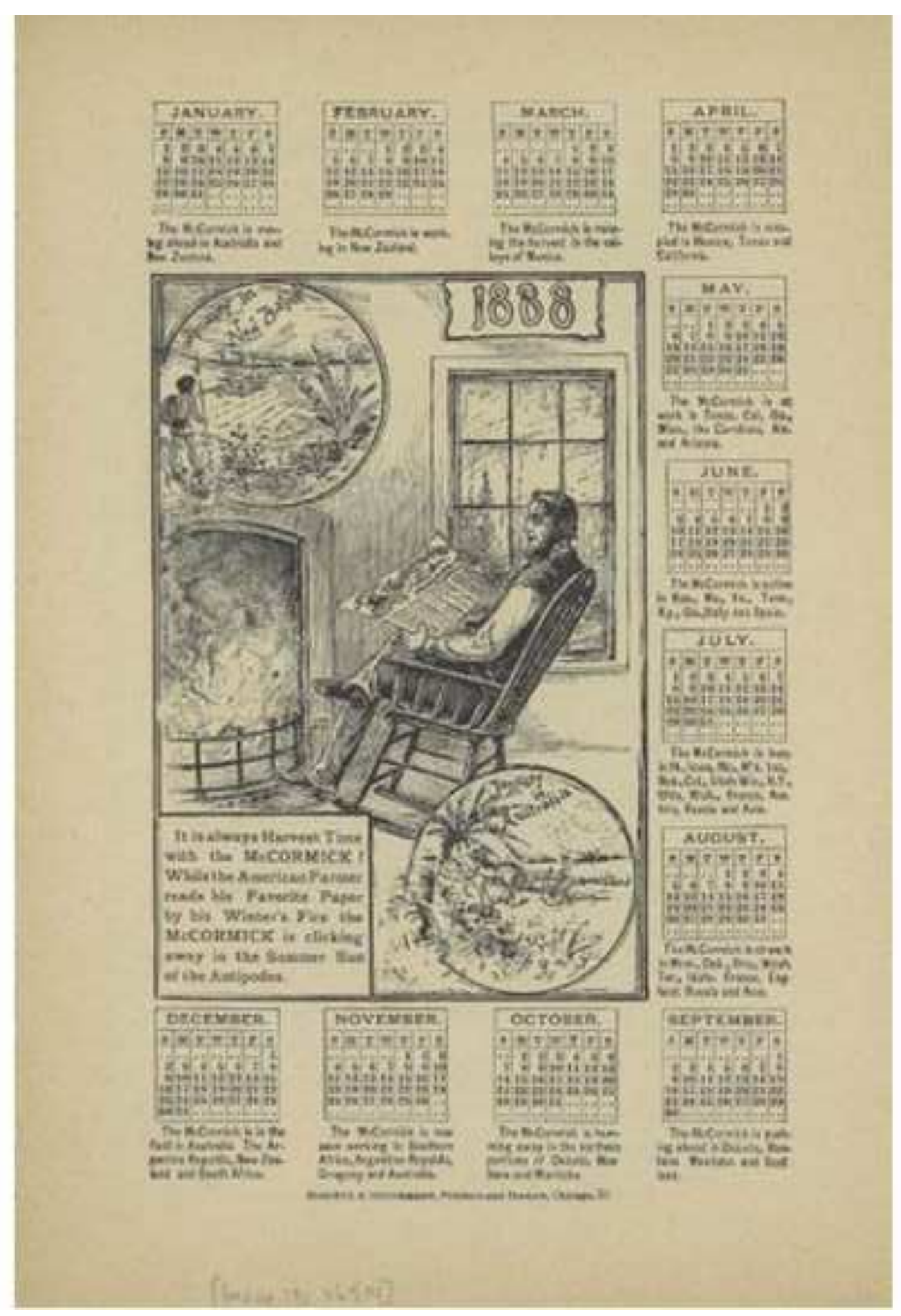




\section{AGRICULTURAL EXTENSION TO THE FARM HOME}

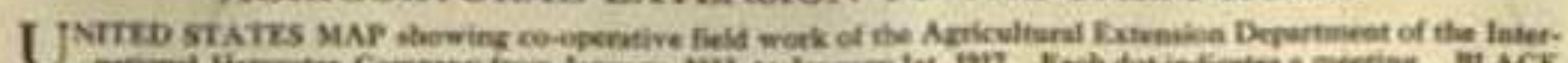

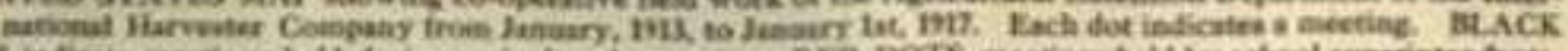

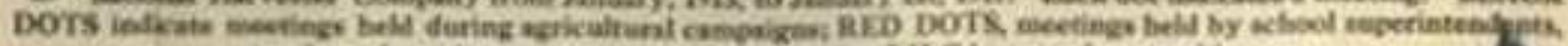

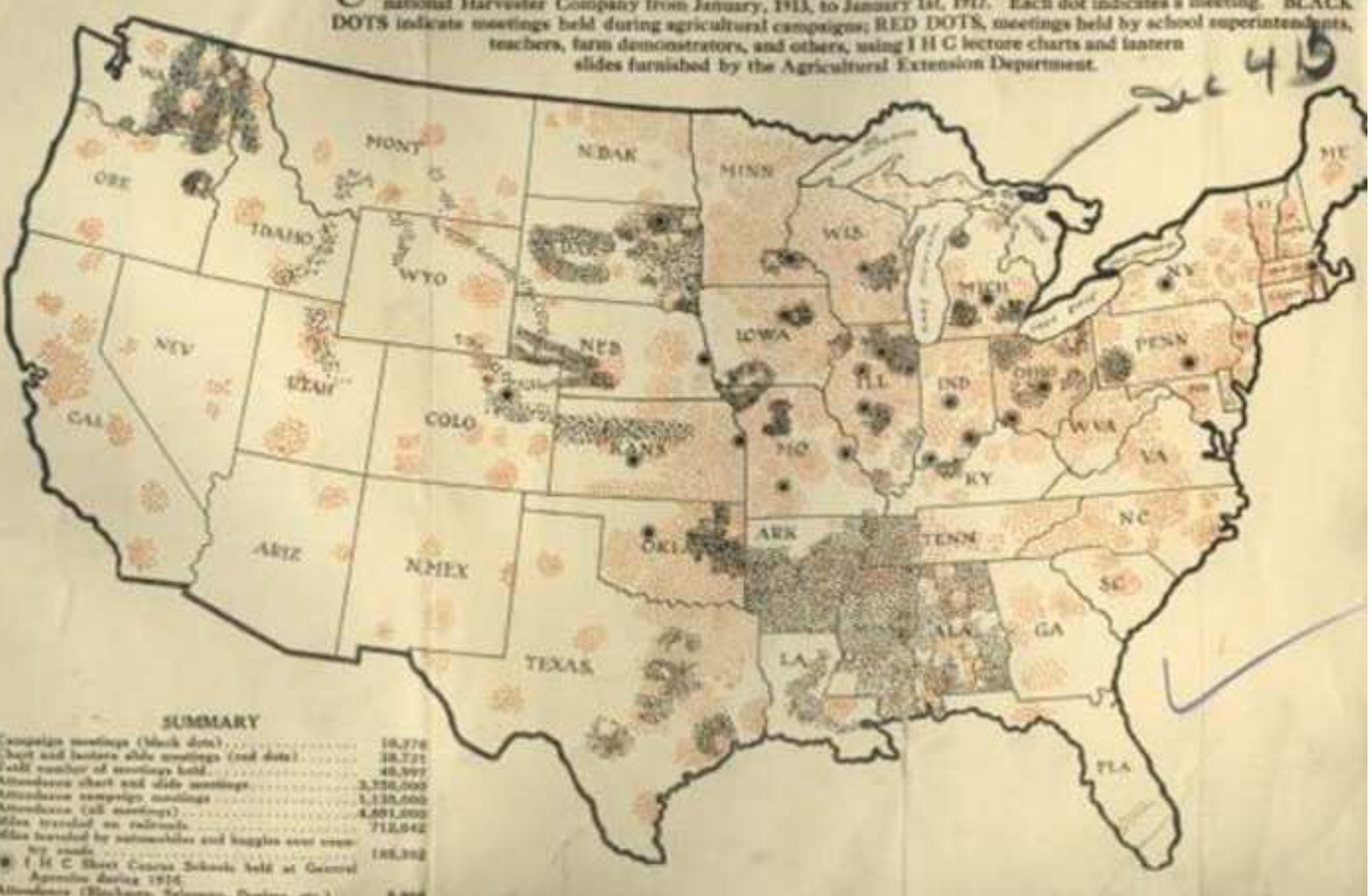

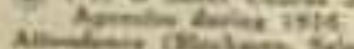

tond 


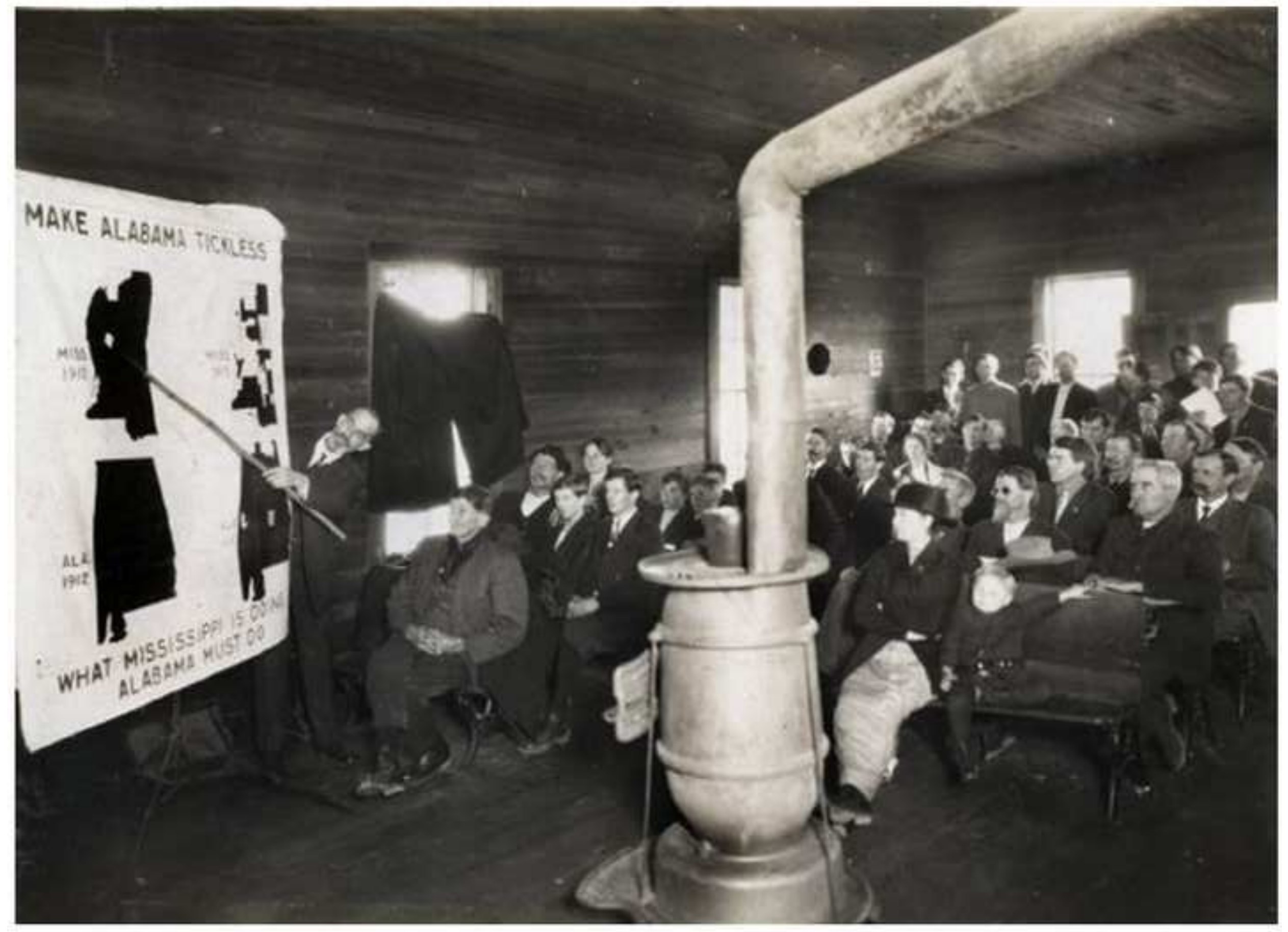




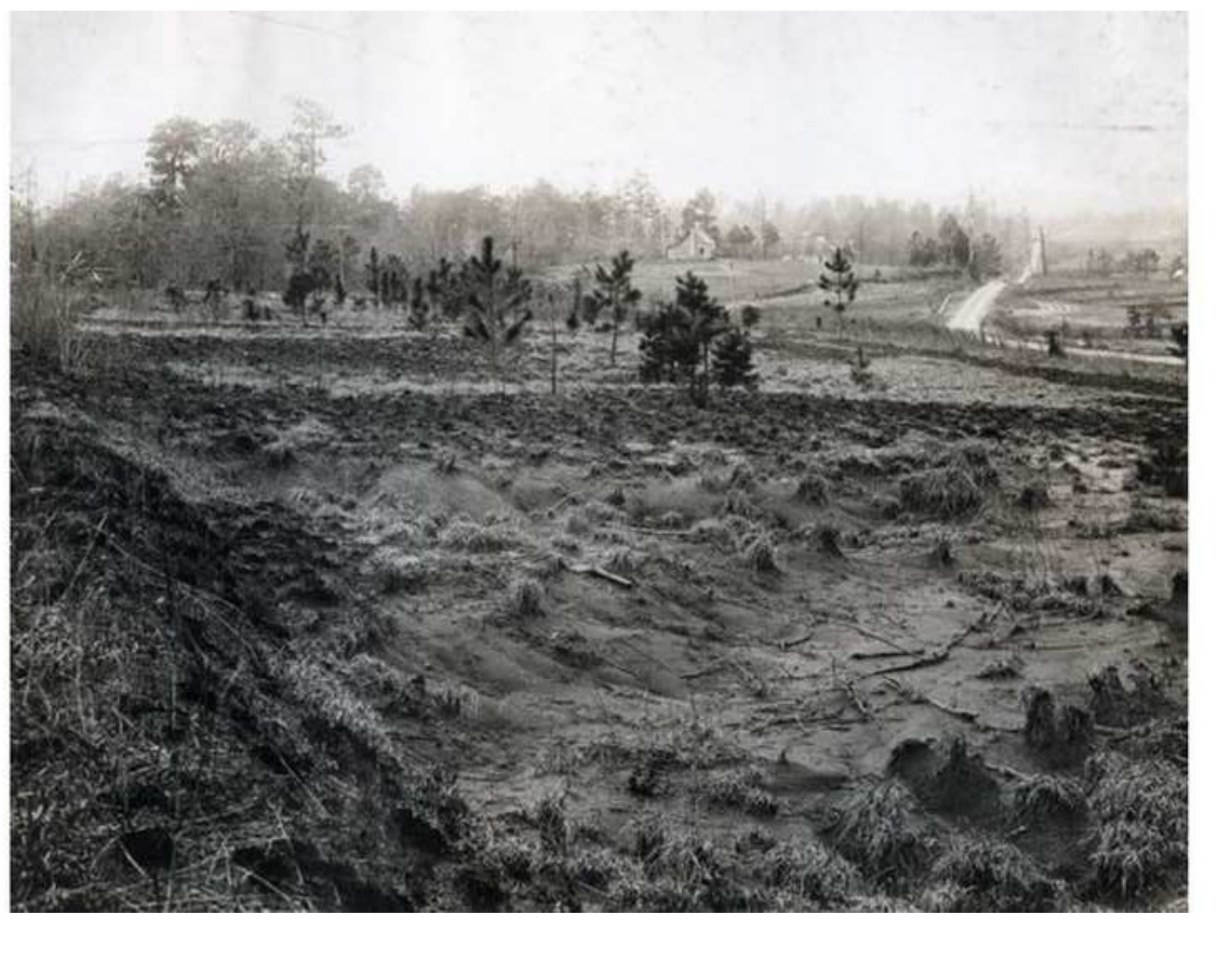

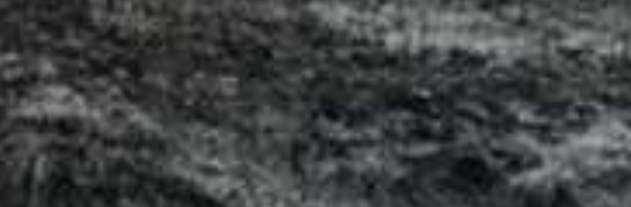
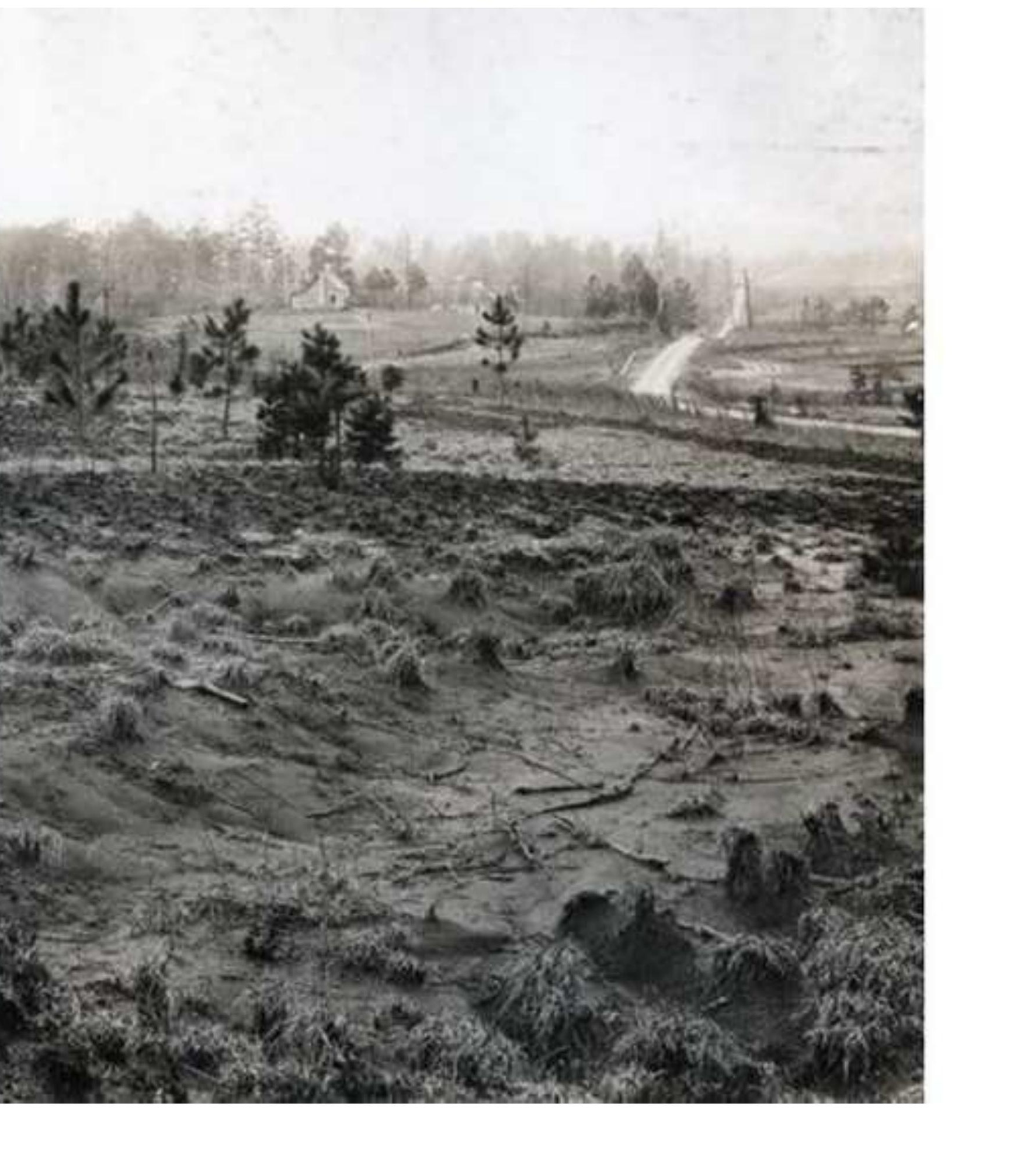

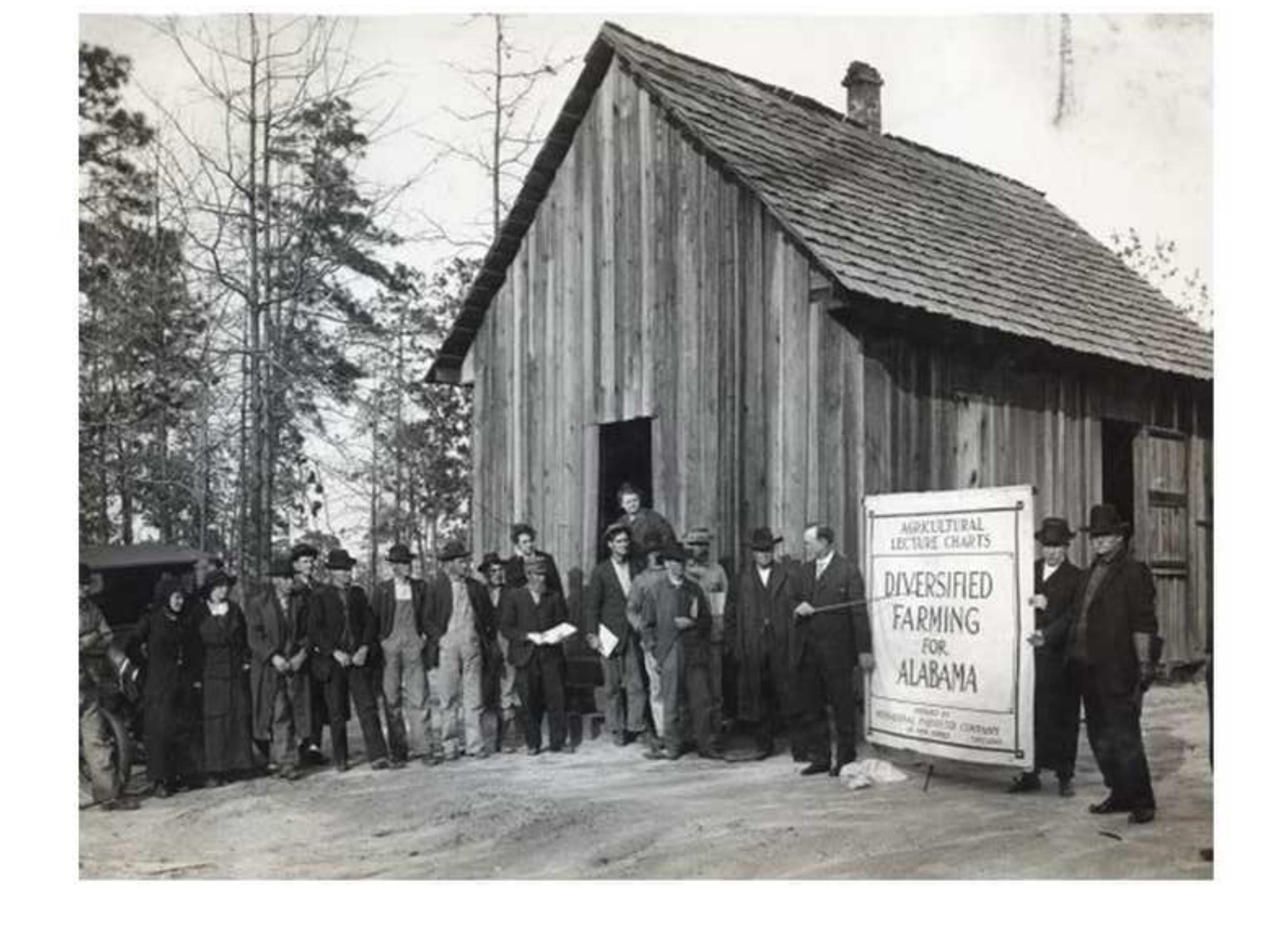


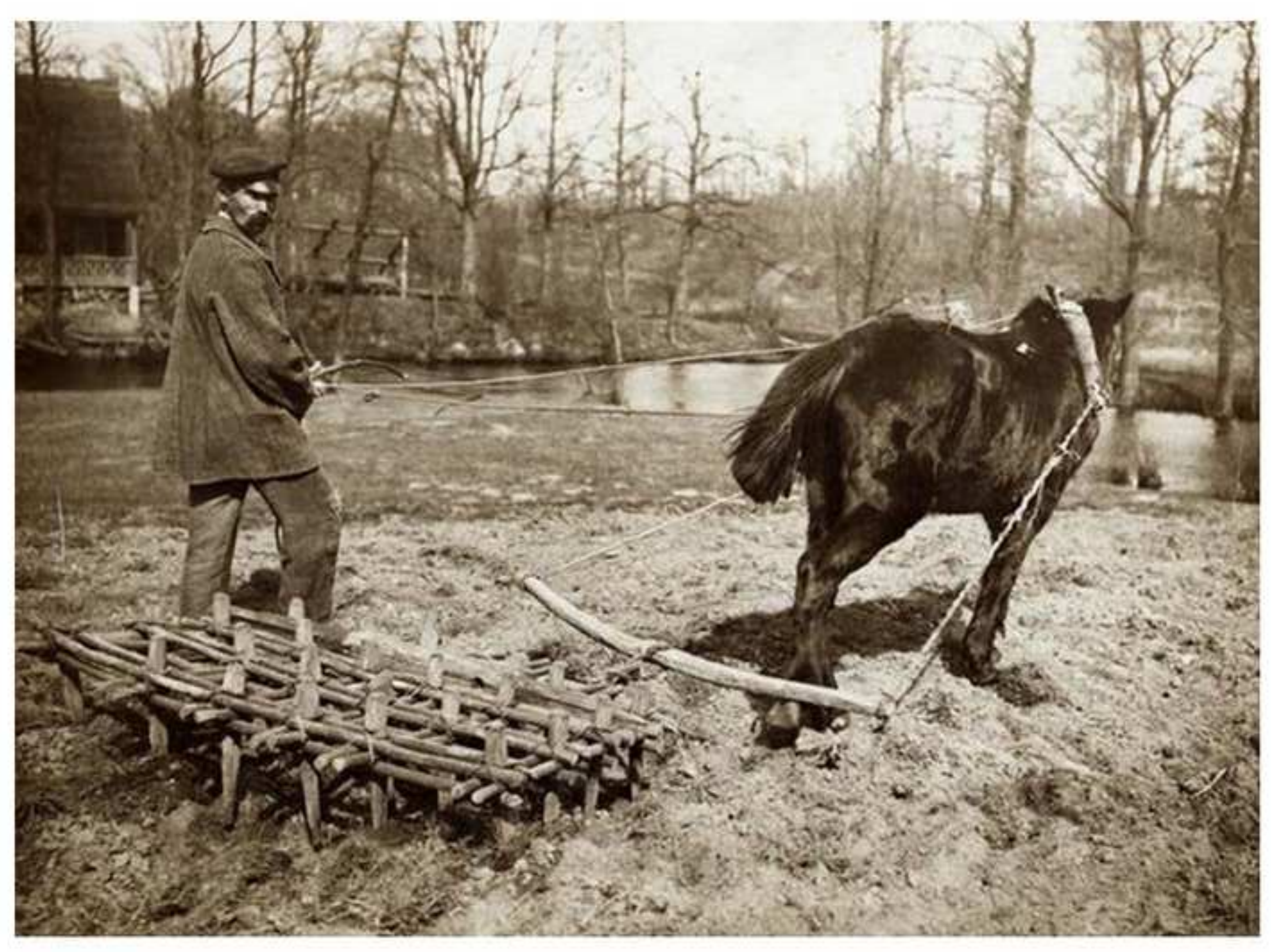




\section{Figure Captions}

Figure 1. Page from Harvest Scenes Around the World depicting different forms of agricultural technology in use in Russia. Source: Harvest Scenes Around the World, Chicago: International Harvester Company of America, 1913.

Figure 2. Page from Harvest Scenes Around the World depicting plowing in Egypt. Source: Harvest Scenes Around the World, Chicago: International Harvester Company of America, 1913.

Figure 3. Photograph of women and children in field with a walking plow, Enon, Alabama, Feb. 22, 1915. Original caption reads: "This picture was not taken in Egypt nor India nor Africa but in Alabama near Enon and shows the primitive methods still in use among the miserably poor colored people of the south." Source: Wisconsin Historical Society, Madison, WI. Image No. 9470 .

Figure 4. Advertising brochure depicting the history of agricultural technology, 1886. Source: Wisconsin Historical Society, Madison WI. Image No. 36208

Figure 5. Page from McCormick catalog titled "It's Always Harvest Time with McCormick." 1888. Source: Wisconsin Historical Society, Madison, WI. Image No. 36501.

Figure 6. Map showing field work of the Agricultural Extension Department of the International Harvester Company from January of 1913 to January 1 of 1917. Source: Wisconsin Historical Society, Madison, WI. Image No. 44253.

Figure 7. Photograph showing Professor Holden at Cottage Hill School, Jefferson County, Alabama, telling the farmers how to eradicate the cattle tick in Alabama, circa 1915. Source: Wisconsin Historical Society, Madison, WI. Image No. 77878. 
Figure 8. Photograph of abandoned cotton field near Meridian, Mississippi, March 18, 1915. Original caption reads: "this field - an abandoned Cotton field near Meridian, Miss. shows how many thousands of acres of good Southern land have been ruined by one crop farming. Year after year the field was planted in cotton and after the cotton was taken off, it was let lay all winter with no protecting crop, or pasture, from the heavy dashing rains of the South, during the winter season, and as a consequence, the fertility of the soil has been literally washed away." Source: Wisconsin Historical Society, Madison, WI. Image No. 75102.

Figure 9. Photograph depicting Professor Clark lecturing to farmers about diversified farming at New Home School, Alabama, March 8, 1915. Source: Wisconsin Historical Society, Madison, WI. Image No. 77987.

Figure 10. Two photographs depicting poor plowing in the South. Source: Alford, G., Diversified Farming in the Cotton Belt, International Harvester Company of New Jersey Agricultural Extension Division, 1914.

Figure 11. Photograph showing a farmer using a homemade harrow in Russia, circa 1917. Original caption reads "Primitive methods of agriculture in Russia (Volga region)." Source: Wisconsin Historical Society, Madison, WI. Image No. 24469. 